\title{
Law Enforcement through Customary Police in Improving the Security for Tourism Investors in Indonesia
}

\author{
Ade Saptomo \\ Faculty of Law \\ University of Pancasila \\ Jakarta, Indonesia \\ adesaptomo@univpancasila.ac.id
}

\begin{abstract}
The study is to examine the concept in improving the mentioned law enforcement through applying the rules involving customary police or security guard, known as Pecalang in Indonesia. The method used here is statutory and conceptual approach to legislation. In collecting the data, documentation and observation were used. Qualitative descriptive method was used in analyzing and presenting the data. The result shows that regional government's capability to formulate the policies related to improve the quality of securities services is needed. Therefore, customary police in security system, as Pecalang in Bali or other areas in Indonesia should be involved in improving the secure for tourism and investor, particularly in limited duties to support the duties of the Indonesian National Police.
\end{abstract}

Keywords-police culture; law enforcement; security; tourism

\section{INTRODUCTION}

When the regional autonomy policy was launched following the fall of the New Order government in 1998, a set of laws on which the law of the regional autonomy movement was issued. Among other things, Law Number 22 Year 1999 on the Regional Government. The policy is intended to authorize local governments to utilize the potential of resources in the region to increase local revenue, which in turn is the welfare of the people. Five years later, the law was revised into Law Number 32 of 2004 which regulates the same. The core of the law is still the same that is encouraging local governments both districts/cities to improve the welfare of the people of their respective regions.

Implementation of regional autonomy has implications for the rise of local governments to explore the potential of local resources. One such effort is to create a safe situation and condition in such a way as to attract investors and tourists to visit the tourism destinations of the regions in Indonesia. Various attractions for people to visit with the aim of investing or visiting for tourism. Regional autonomy regulated in local government law is one of the legal umbrella that is expected to encourage local governments to explore the potential of each region also in order to attract investors. It is not enough that the local government only introduces its natural potential. That is, other efforts should be made in an effort to form investment attractiveness on a continuous basis from time to time, such as security.

Authorities so need to safeguard the rights of individuals against abuse in day-to-day dealings while providing protection [1]. Exercising autonomy implies assuming responsibility [2]. By comparing the innovative behaviour of these firms with that of multinationals with highly centralised resources they observed that relatively autonomous subsidiaries created and diffused more innovations [3].

In general, investment will enter an area depending on the attractiveness of the area, and the existence of a conducive investment climate. The success of the region to increase the attractiveness of investment is, among others, the ability of regions in formulating policies related to investment and improving the quality of service to the community. It is also important to note in an effort to attract investors, the development of human resources and infrastructure in the broad sense given the inadequate infrastructure will hamper the time and costly. In the perspective of tourism investment, legal certainty, the consistency of law enforcement becomes a major element in an effort to increase the security of tourism destinations. Thus, this study is aimed at examining the law enforcement by the culture police in an effort to improve the security of tourism destinations in Indonesia.

\section{METHOD}

The method used here is statutory and conceptual approach to legislation. In collecting the data, documentation and observation were used. Qualitative descriptive method was used in analyzing and presenting the data. The data were obtained from literature studies and books of the shrimp that govern corruption. Documentation technique is a technique done to collect data of this research. The data were analyzed by qualitative descriptive method which includes deeply examining the meaning and making inferences to it; then describes the results of the obtained. The legal content was analyzed by hermeneutic technique to understand the definite meaning of each content of the provision made by the government about the act of eradicating corruption and to explain it conceptually by making the sense. 


\section{RESULT AND DISCUSSION}

\section{A. Law Enforcement}

But until now, the approach that has not changed significantly is the top down approach to the bottom up and has not used the cultural potentials of people in tourism destination areas to be included in the law enforcement process. Law enforcement is still seen as the responsibility of the state, as stated in the 1945 Constitution that the state is obliged to protect the entire Indonesian nation and the entire Indonesian blood spill. In the era of regional autonomy as it should now be in addition to the government, the role of the community is also included in the protection of the community, especially the tourism destinations for violations or other crimes, below are four police approaches used in the framework of law enforcement.

Constitutionally, the state administration and state administration of Indonesia is based on law. As mentioned in the 1945 Constitution of the Republic of Indonesia Article 1 Paragraph 3 that the state of Indonesia is a state of law (rechtstaat) is not a state of power (machtstaat). One of the logical juridical consequences of the constitutional state is the rule of law. That is, law enforcement must be implemented. In practice the enforcement of such law enforcement may, on the one hand, take place in accordance with applicable laws, but on the other hand, it may also be inconsistent with legislation, even on the ground there are legal irregularities. If there is a deviation, then the main choice is law enforcement should come true.

One important point regarding this law enforcement discourse is when legal objectives are established to protect the interests of the community and the role of law is played by law enforcement. In this sense, the role of law enforcers is important to be analyzed, especially in law enforcement in the judicial arena by judges, prosecutors, police, and lawyers commonly called Catur Wangsa. In relation to the government policy on regional autonomy where local governments should dig their own potentials, in the context of law enforcement, of course it is related to local community perspective, since the law cannot be separated from society and vice versa.

\section{B. Police as Law Enforcers}

Referring to the concept that good law is law cannot be separated from the local social culture factor where the law is located, then the good philosophy is a pill that cannot be separated from the social culture factor where the police work. To answer the good police, in the context of society, so that the police can work maximally in the community, then assuming the CivPol is an option. The Indonesian Police itself consists of four types, namely Civilian Police, Military Police, Secret Service, and Sleep Police (Ramp) as stated by Chaeruddin Ismail. One type of police that is expected to apply to Indonesian society in the Reformation Era today is the CivPol. In its development, in addition to the Civil Police there is also another approach that is, Police Culture. The opportunity for the existence of the Cultural Police can be interpreted in the article as intended by Article 57 of Law Number 22 Year 1997 on Narcotics that:
- The public has the widest opportunity to participate in assisting the prevention and eradication of drug abuse and illicit trafficking.

- The public shall be obliged to report to the competent authority in case of abuse and illicit trafficking of narcotics.

- The Government is obliged to provide security guarantees and protection to the complainant as referred to in paragraph [2].

The first and second points are important in today's era. In relation to these two issues, it is interesting to answer the question of what law enforcement concept should be done by the Police of the Republic of Indonesia to make it possible for the public to have the widest possible opportunity to participate in assisting law enforcement efforts. In an effort to answer the main problem there are some concepts about what should be done by the police institution has been proposed by some scholars, but the concept is still driven by a top down paradigm even though the substance of the concept has been colored social values, such as Civil Police, Community Policing or socalled Community Police (Polmas).

There is a concept that is considered really bottom up. That is, the 'police' born in the culture of Indonesian society itself, even its birth before the Republic of Indonesia itself was established so that the Police referred to each unit of Indonesian society is different. To that end, in this opportunity introduced Police Culture derived from the people of Indonesia, such as Police Culture Society Minangkabau, Bali, and Madura. The existence of the Cultural Police is very necessary to be empowered to assist the task of the Indonesian National Police in creating a sense of security. But to clarify the difference, the concepts of Civil Police, Community Policing, and the new Cultural Police in question are mentioned.

\section{1) Civil Police}

After the Reformation of 1998, the Indonesian Police movement was on the right line, for example the policy of separating its position from the military. The separation of the police from the military is certainly not merely a structural separation, but also cultural. Perhaps a change of Culture will take a long time so that before it comes to the separation as people imagine there are still militaristic practices. This impression is not ridiculous because the police who now still hold a strategic position are nothing but a product of militaristic education. But at least, conceptually there has been a policy of police separation from the military to be positively welcomed. To that end, the meaning of separation of the police from the military does not stop at the structural level, but the Police characterize the character becomes the main agenda in the future.

But civil Police referred to SatjiptoRahardjo (2007) is how Police have civil character. SatjiptoRahardjo proposed at least four (4) steps that the Police should take. These four steps are (1) closer to the community; (2) making accountable to society; (3) replace from relying on destruction by serving and helping (4) sensitizing and involving to the civil affairs of the citizens, such as helping the weak, ignorant and confused, frustrated, 
unemployed, sick, hungry, and desperate. This is an effort presented by SatjiptoRahardjo which he says is a big and heavy work. Yet even in such a large and heavy manner, the policies that should be issued by all leaders at the headquarters level remain an important and necessary and awaited option in the future.

In my view, the concept of Civil Police is intended for law enforcement, no resistance from society and society does not assume that the Police is part of the military. For that, there is actually another concept more sharp and concrete, in addition to the police officers change on the level of behavior and also on the cultural or ideological level, but also on the division of police roles to community institutions that Culture has been born, live and grow in local localcommunity. Of course, not on all police duties pertaining to crime and lawless, but limited police tasks involving certain legal cases and at the same time police are on the second line of the Cultural Police.

\section{2) Community Police}

There is a view in the UK, commonly called Community Policing (CP). The CP concept is classified as a modern concept that emphasizes how the Policeman moves to carry out its tasks that must be accounted for. This concept emphasizes the solution of problem-oriented law, in which the Police in performing their duties emphasizes in advance the problems underlying the police to act, not to be oriented to waiting oriented nature, ie the police awaiting a public report or request that there is something to be dealt with by the police. Such an approach, making the Police inactive but waiting for the reporting of people who go to the police, and then performed the police action.

Based on these conditions, the CP concept is a police approach that closer to the community and its citizens. Here the police feel it is more important to give accountability to the community based on the needs of the community rather than to the superiors on the request of targets the amount to be resolved by the police within a certain time. In this sense, back to the main task of the police, namely, first, the police as an institution in charge of maintaining and maintaining social order and order in order to achieve a safe, peaceful and peaceful life. Second, the police as an institution that plays a role in law enforcement and norms that live in society.

This concept is different from the Civil Police discussed by SatjiptoRahardjo above because the concept of the Civil Police is more on changing the symbols used by the police and with the symbol is expected to change the behavior of the police in the face of the perpetrators of crime and lawlessness. While the concept of Community Policing or Community Policing emphasizes on accountability to society than to the boss as its corps. This is important because the community's involvement to dare to immediately report the citizens who have committed crimes or other violations of law. But the core of this concept is also the effectiveness of police tasks in law enforcement exactly as defined in the concept of Civil Police.

Formally, it is the Police of the Republic of Indonesia through the Decree of the Chief of Police. Pol.:Skep/737/X/2005 dated October 13, 2005 on Policies and Strategies for Implementation of Community Policing Model in the implementation of Polri's duty to apply Community
Policing model. This concept is more emphasizing the empowerment of the community to participate to make himself as a community policeman in the sense that the participation of the community to participate in preventing the occurrence of crime and other violations of the law by reporting. But on the other hand, the public is only emphasized to participate actively report alone, rather than directly prevent a crime committed by its citizens.

To that end, the authors propose the next concept that is considered deeper, namely the empowerment of Cultural police in which the community not only stop to report, but also directly participate directly to the citizens who commit a crime or violation of certain laws because the community as the birthplace of citizens, where citizens live, and where citizens develop more know than the police themselves. That is, the community through the elders of the community or elders of adatnya will better know the answer why there are crimes, why citizens commit crimes, as well as how to take precautions.

\section{3) Cultural/Customary Police}

Authors in various places and occasions once conveyed the concept of Police Culture police. Indeed, in the framework of law enforcement both as a judicial applicant and as a servant of society there has been an approach ever undertaken by the police of the Republic of Indonesia in the era of regional autonomy. For example, a top down paradigm shift to bottom up, from being served to serve, from militaristic to civilian styles. However, it seems that the wider community wants not only to stop efforts to change the militaristic behavior to become civilian as it is known by the Civilian Police. The concept of Civil Police is more emphasis on changing the symbols used by the police and with the symbol is expected to change the police behavior in serving the community, in order also in the face of the perpetrators of crime and lawlessness. Nor does it stop at Community Policing (CP) which is now encouraged. CP emphasizes the empowerment of the community to participate in making itself a community policeman in the sense that the participation of the community to participate in preventing the occurrence of crimes and other violations by reporting. The latter concept carries the consequence that the public is only emphasized to participate actively reporting, rather than to prevent directly an act of crime committed by its citizens.

In this regard, in my view, the approach of law enforcement by the police in this reform era and in accordance with the plural and multicultural conditions of the Indonesian Nation is not just a police approach in the form of Civil Police by showing police ties, not enough polite police by conveying respect citizens, but more fundamentally than that, that is to act as a potential empowerment of the police that are socially and culturally indeed have been born, alive, and developed in the local community. The people of this archipelago actually have an informal institution that runs the limited tasks of the police of the Republic of Indonesia. UbiSocietasUbiIus, where there is society there is law. The meaning behind the phrase is part of the role of formal police institutions established through legislation can be played by the citizens themselves. Selected residents with customary attributes or local community symbols are referred to as the Cultural Police. 


\section{CONCLUSION}

Thus, the Cultural Police as I am referring to in this paper is a subsystem of a security system that was born, grew, developed and internalized into Indonesian society in general and in particular the Indigenous Peoples of Nusantara. For example, in the context of Balinese society, the Cultural Police are played by Pecalang (active), and many other forms of Indonesian archipelago society. That is what I mean as a Cultural police whose existence is much more familiar with citizens and much more settled into the Indigenous Peoples of the Archipelago as he was born, live, grow, and develop in the community where they are.

Thus, the Cultural Police is one of the strategic alternative solutions for the Police of the Republic of Indonesia in the future, while the concept of Community Policing is more fitting applied to the urban community which involves the role of RukunTeteangga/RT (Neighborhood Association) and RukunWarga/RW (Citizens Association) Chairman. With this model of the Cultural Police, the reason for the inadequate ratio of police personnel, as long as it is conveyed to argue that the police are ineffective becomes less relevant because what is actually required is the authority (gezag), on the contrary with the Cultural Police the police authority in society will increase as a result of society involved socially and culturally. The implication is that the government at a certain level need not hasten to increase the number of police personnel, but the grounded concepts and strategies will improve the quality and image of the Indonesian National Police.

\section{Pecalang as Local Police}

Safety condition in a region is the condition sine quanon for investment attractiveness of any certain region. Investor is assured to have perspective that any business activity will never run smoothly without supported by security, convenience, public openness behavior, and political condition in the region where such business activity is undertaken. Bali Regency, as we watched over the audio visual in many printed media or television of course serious barrier to any prospective investor to invest business in the region. In small-scale, it is required to take into account security disorder that comes from unaccountable person around business place is conducted. Therefore, security assurance from the security officers becomes a highly expected factor.

Convenient factor is also important, we still well remembered, for instance flood in Jakarta and in some other regions occurred recently. Apparent policy in anticipating flood. Therefore in Padang city, the image of Padang city as flood city must be promptly deleted, otherwise golden opportunity in attracting investors to undertake their business activities in this city will be lost. Bali as destination of tourism has also local wisdom, that's Pecalang. The role of Pecalang in improving the convenient in Bali is very important. Meaning that this is also decreasing barrier factor that cause investor is less convenient.
It means that (1) socio-cultural factor is also important to be taken into account by investor recalling public openness to business community will make their business activities run smoothly, (2) the supporting force to business activities is seen not only from acceptance to existence of business activities, but also matters related to acceptance of the local community as well as cultural match between the investor's culture and the local wisdom of Indonesian people's culture becomes important. Law enforcement by cultural police becomes the ground of improving the safety and entrance of investment from another region and visitors who have intention to conduct business activities in the tourism destination region.

Other hand, with the policy of the Cultural Police, the community not only stops reporting but is also given space to serve legal needs as well as to deal directly with culture to some of its citizens who commit crimes or violations of the law. In addition, the Cultural Police are more understanding, knowing, and better understanding than the country's own formal police in terms of the birthplace of citizens, residences of citizens, and places of citizenship. Of course, modern or metropolitan societies can use the RT and Rw heads or in traditional societies to utilize the elders of their community or adat elders because they will know better the answers to why crimes, who committed crimes, and how to take precautions. While at the same time, the position of the Police Force of the Republic of Indonesia or the Formal Police is more of a role as a companion of the Cultural Police who will work when the first so-called police are unable to face legal requirements or minor offenses or other violations of law.

\section{ACKNOWLEDGEMENT}

The author would like to thank all the parties who have helped and contributed in the writing of this article, both those who contribute in the form of funding and critical ideas. Hopefully this paper can be useful theoretically and practically for the addition and development of knowledge, especially in the field of legal science.

\section{REFERENCES}

[1] M. Fallon-Kund, M. Coenen, and J. E. Bickenbach, "Balancing autonomy and protection: A qualitative analysis of court hearings dealing with protective measures," Int. J. Law Psychiatry, vol. 53, pp. 69-76, 2017.

[2] B. Maier, "Is the narrow concept of individual autonomy compatible with or in conflict with Evidence-based Medicine in obstetric practice?: A philosophical critique on the misapplication of the value concept 'autonomy,'” Woman - Psychosom. Gynaecol. Obstet., vol. 1, no. C, pp. 40-49, 2014.

[3] S. Beugelsdijk and B. Jindra, "Product innovation and decision-making autonomy in subsidiaries of multinational companies," J. World Bus., vol. 53, no. 4, pp. 529-539, 2018. 